\title{
Congenital Phrenic Nerve Injury
}

National Cancer Institute

\section{Source}

National Cancer Institute. Congenital Phrenic Nerve Injury. NCI Thesaurus. Code C103156.

Damage to the phrenic nerve that is present at birth. 